\title{
EVALUASI PENGELOLAAN DANA DESA DI DESA BONE KANCINTALA KECAMATAN BONE KABUPATEN MUNA
}

\author{
Oleh \\ Hasbudin $^{1}$, Wa Ode Aswati ${ }^{2}$, Nirwana $^{3}$
Jurusan Akuntansi Fakultas Ekonomi dan Bisnis Universitas Halu Oleo Kendari Sulawesi Tenggara

\begin{abstract}
ABSTRAK
Dalam pelaksanaan pengelolaan dana Desa, Desa Bone Kancintala masi Mengalami beberapa permasalahan yakni: Pembangunan fisik yang terbengkalai seperti pembangunan pasar dan jalan karena waktu yang dibutuhkan sudah melebihi batas waktu yang telah ditentukan. Disamping itu kepala desa sendiri tidak transparan masalah anggaran mengenai program yang dibangun. Selain itu, perencanaan program dana desa dalam kurun waktu satu tahun terdapat dua tahap namun pada tahap kedua mengalami keterlambatan atau belum bisa dilakukan pencairan dana sebab program pada pencairan dana tahap pertama belum selesai dikerjakan, peristiwa ini terjadi karena kualitas sumber daya aparatur yang dimiliki desa yang masih rendah. Penelitian ini bertujuan untuk mengevaluasi proses pengelolaan dana desa dari tahap perencanaan dan pertanggungjawaban di Desa Bone Kancintala Kecamatan Bone Kabupaten Muna. Metode pengumpulan data yang digunakan dalam penelitian ini adalah wawancara dan dokumentasi. Sampel dalam penelitian ini terdiri dari Kepala Desa, Sekretaris Desa, Bendahara Desa, serta Kabid Desa Bone Kancintala. Selanjutnya hasil penelitian dianalisis melalui metode analisis deskriptif yang menjelaskan tentang proses evaluasi dana desa dari tahap perencanaan hingga pertanggungjawabannya. Data yang digunakan memilih data primer dan data sekunder.

Hasil penelitian menunjukan bahwa Pada tahap perencanaan Dana Desa di Desa Bone Kancintala Kecamatan Bone Kabupaten Muna telah menerapkan prinsip partisipatif dan transparansi dan Tahap pertanggungjawaban pengelolaan Dana Desa di Desa Bone Kancintala Kecamatan Bone sudah Akuntabel dan secara teknis sudah baik.
\end{abstract}

Kata kunci: Dana Desa, perencanan dan Pertanggungjawaban.

\section{ABSTRACT}

This study aims to determine the Evaluation process of village Fund Management from the planning and accountability stages in Bone Kancintala village, Bone District, Muna Regency.Data collection methods used in this study were interviews and documentation. Furthermore, the results of the research were analyzed through descriptive analysis method which describes the process of evaluating village funds from the planning and accountability stages.The data used selects primary data, namely data from Bone Kancintala Village, Bone District, Muna Regency.

The results showed that at the planning stage of village, Bone District, Muna regency had implemented participatory principles and transparency and the accountability stage for managing village, funds in Bone Kancintala Vilagge, Bone District was accountable and technically good.

Keywords: Village Funds, planning, and accountability. 


\section{PENDAHULUAN}

Undang-Undang No.6 Tahun 2014 tentang Desa tersebut, memberikan perubahan secara signifikan dalam tata kelola pemerintahan Desa. Dari sisi regulasi desa, desa (atau dengan nama lain telah diatur khusus atau tesendiri) tidak lagi menjadi bagian dari UU No.32 Tahun 2004 tentang Pemerintahan Daerah.

Selanjutnya desa mengalami reposisi dan pendekatan baru dalam pelaksanaan pembangunan dan tata kelola pemerintahannya. Pada hakikatnya UU memiliki visi dan rekayasa yang memberikan kewenangan luas kepada desa di bidang penyelenggaraan pemerintahan desa, pelaksanaan pembangunan desa, pembinaan kemasyarakatan desa, dan pemberdayaan masyarakat desa berdasarkan prakarsa masyarakat, hak asal usul, dan adat istiadat desa.

Dalam lingkup desa itu sendiri dikenal suatu istilah yaitu kegiatan pemerintah desa, lebih jelasnya, kegiatan pemerintah desa dapat dikategorikan merupakan penyelenggaraan tata kelola desa (disingkat penyelenggaraan desa) oleh perangkat desa atau yang dikenal selama ini sebagai "pemerintahan desa", dimana Kepala Desa adalah pelaksana kebijakan. Sedangkan Badan Permusyawaratan Desa dan lembaga pembuat dan pengawas kebijakan (Peraturan Desa). Pengelolaan keuangan desa menjadi wewenang desa yang dijabarkan dalam peraturan desa (perdes) tentang anggaran dan pendapatan belanja desa (APBD). Dengan sumber pendapatan yang berasal dari pendapatan asli desa seperti hasil usaha desa, hasil swadaya dan partisipasi, hasil gotong royong dan lain-lain pendapatan asli desa yang sah.

Desa Bone Kancintala menerima alokasi dana desa yang diharapkan dapat meningkatkan kesejateraan masyarakat desa, yang berdampak positif bagi upaya penanggulangan kemiskinan bagi penyediaan pemenuhan kebutuhan dasar masyakat, pembangunan sarana dan prasarana, pengembangan potensi ekonomi lokal dan pemanfaatan sumber daya alam dan lingkungan secara berklanjutan. Desa Bone Kancintala menerima bantuan keuangan desa dengan jumlah yang sangat besar berikut jumlah pendapatan Desa Bone Kancintala tahun anggaran 2019 dapat dilihat pada table berikut :

\section{Tabel 1.1}

Tabel Penerimaan Dana Desa Tahun 2019

\begin{tabular}{|l|r|}
\hline Tahun & Total Penerimaan (Rp) \\
\hline 2019 & $906.543 .138,00$. \\
\hline
\end{tabular}

Sumber: Pemerintah Desa Bone Kancintala

Dari tabel diatas dapat diketahui bahwa total penerimaan Dana Desa pada tahun 2019 sebesar Rp. 906.543.138,00.

Pengelolaan Dana Desa banyak dilakukan di Desa Bone Kancintala sebagai wujud kebijakan pusat untuk mensejahtrakan masyarakat Desa Bone Kancintala , salah satunya adalah pemberdayaan masyarakat dan menyiapkan sarana dan prasarana yang dibutuhkan oleh masyarakat dengan tujuan agar masyarakat memperoleh kemudahan, sebagai contohnya yaitu pembuatan lapak pasar dan jalan tani sehingga dengan demikian menciptakan roda perputaran ekonomi yang stabil dan yang diinginkan oleh masyarakat Desa Bone Kancintala.

Dalam pelaksanaan pengelolaan Dana Desa, Desa Bone Kancintala Kecamatan Bone Kabupaten Muna masi mengalami beberapa permasalahan yakni seperti: pembangunan sarana fisik yang terbengkali, dimana waktu pekerjaan yang dibutuhkan suda melebihi batas waktu yang telah ditentukan.disamping itu kepala desa sendiri tidak transparan masalah anggaran mengenai program yang dibangun. Selain itu, perencanaan 
program dana desa dalam kurun waktu satu tahun terdapat dua tahap namun pada tahap kedua mengalami keterlambatan atau belum bisa dilakukan pencairan dana sebab program pada pencairan dana tahap pertama belum selesai dikerjakan atau kegiatan yang dibangun belum rampung, peristiwa ini terjadi karna kualitas sumber daya aparatur yang dimiliki desa yang masih rendah. Pembangunan desa seharusnya dilakukan dengan kerja sama antara pihak pemerintah desa, swasta, maupun masyarakat. Jika hanya dilakukan oleh satu pihak saja maka pembangunan yang dilaksanakan tidak akan terwujud dengan baik dan tidak akan mencapai sasaran yang telah direncanakan. Untuk mencapai sasaran tersebut pembangunan di desa khususnya, diharapkan keseluruhan Pemerintah desa dapat mengoptimalkan anggaran Keuangan Alokasi Dana Desa yang dimiliki sehingga penggunaan Alokasi Dana Desa ini dapat menggerakkan roda perekonomian desa. Oleh karena itu, pemerintah desa dibantu oleh tenaga pendamping profesional agar dapat mengelola keuangan desa dan menerapkan akuntansi keuangan desa sesuai peraturan perundang-undangan yang berlaku yakni permendagri No. 113 Tahun 2014. Berdasarkan latar belakang yang telah diuraikan diatas, maka rumusan masalah dalam penelitian ini adalah Bagaimana pengelolaan Dana Desa Menurut Permendagri No.113 Tahun 2014 dari tahap perencanaan dan pertanggungjawaban di Desa Bone Kancintala Kecamatan Bone Kabupaten Muna?

Berdasarkan rurmusan masalah yang telah disampaiakan, maka yang menjadi tujuan penelitian ini adalah untuk mengetahui proses evaluasi pengelolaan dana desa di Desa Bone Kancintala Kecamatan Bone Kabupaten Muna dari tahap perencanaan dan pertanggungjawaban.

\section{Konsep Desa}

\section{TINJAUAN PUSTAKA}

Undang-Undang Nomor 6 Tahun 2014 tentang Desa, yang dimaksud dengan desa adalah desa dan desa adat yang disebut dengan nama lain, selanjutnya disebut desa adalah kesatuan masyarakat hukum yang memiliki batas-batas wilayah yang berwenang untuk mengatur dan mengurus urusan pemerintahan, kepentingan masyarakat setempat berdasarkan prakarsa masyar.akat setempat, hak asal-usul dan hak tradisional yang diakui dan dihormati dalam sistem pemerintahan Negara Kesatuan Republik Indonesia.

Untuk mengatur serta menjalankan suatu kewenangan dalam mengatur desa disebut pemerintah desa. Pemerintah Desa adalah kepala desa atau yang disebut dengan nama lain dibantu perangkat desa sebagai unsur penyelenggara pemerintah desa. Badan Permusyawaratan Desa (BPD) merupakan lembaga perwujudan dalam demokrasi penyelenggaraan pemerintah desa. Anggota BPD ialah wakil dari penduduk desa bersangkutan berdasarkan keterwakilan wilayah. Anggota BPD terdiri dari ketua RW, pemangku adat, golongan profesi, pemuka agama atau tokoh masyarakat lainnya.

Hasbudin, dkk (2015) menyatakan desa adalah bentuk pemerintahan terkecil yang ada di negeri ini. Luas wilayah desa biasanya tidak terlalu luas dan dihuni oleh sejumlah keluarga. Desa dipimpin oleh seorang Kepala Desa yang diangkat melalui pemilihan umum yang biasa disebut PILKADES yang dipilih oleh warga desa. Kepala desa menjabat selama 6 tahun dan dapat menjabat selama 2 periode. Kepala Desa biasanya adalah warga desa yang berdomisili di desa tersebut.

\section{Keuangan Desa}

Undang-Undang Nomor 6 Tahun 2014 Pasal 71 ayat 1, menyatakan bahwa keuangan desa adalah hak dan kewajiban desa yang dapat dinilai dengan uang serta segala sesuatu berupa uang dan barang yang berhubungan dengan pelaksanaan hak dan kewajiban desa. Sedangkan Nurcholis (2011) menyatakan bahwa keuangan desa adalah semua hak dan kewajiban dalam rangka penyelenggaraan pemerintahan desa yang dapat dinilai dengan 
uang, termasuk di dalamnya segala bentuk kekayaan yang berhubungan dengan hak dan kewajiban desa tersebut. Keuangan desa berasal dari Pendapatan Asli Desa,AnggaranPendapatan dan Belanja Daerah (APBD) dan Anggaran Pendapatan dan Belanja Negara (APBN).

Sujarweni (2015) menyebutkan bahwa akuntansi desa adalah pencatatan dari proses transaksi yang terjadi di desa, dibuktikan dengan nota-nota kemudian dilakukan pencatatan dan pelaporan keuangan sehingga akan menghasilkan informasi dalam bentuk laporan keuangan yang digunakan pihak-pihak yang berhubungan dengan desa.

\section{Pengelolaan Keuangan Desa}

Peraturan Menteri Dalam Negeri Nomor 113 Tahun 2014 tentang Pengelolaan Keuangan Desa, dinyatakan bahwa pengelolaan keuangan desa adalah keseluruhan kegiatan yang meliputi perencanaan, pelaksanaan, penatausahaan, pelaporan dan pertanggungjawaban keuangan desa. Pengelolaan keuangan desa merupakan rangkaian siklus yang terpadu dan terintegrasi antara satu tahapan dengan tahapan lainnya. Ini bertujuan untuk memudahkan dalam pelaksanaan pengelolaan keuangan desa, sehingga tidak timbul multitafsir dalam penerapannya. Dengan demikian desa dapat mewujudkan pengelolaan keuangan yang efektif dan efisien.

Prinsip utama yang mendasari pengelolaan keuangan desa (Mardiasmo, 2002) yakni prinsip transparansi atau keterbukaan. Transparansi di sini memberikan arti bahwa anggota masyarakat memiliki hak dan akses yang sama untuk mengetahui proses anggaran karena menyangkut aspirasi dan kepentingan masyarakat, terutama pemenuhan kebutuhankebutuhan hidup masyarakat banyak. Dari uraian diatas menjelaskan bahwa pembangunan merupakan perpaduan antara partisipasi masyarakat dan kegiatan pemerintah.Pemerintah berkewajiban menyediakan prasarana-prasarana sedangkan selebihnya diberikan kepada masyarakat itu sendiri, karena pada hakekatnya pembangunan itu dilaksanakan oleh masyarakat itu sendiri. Jadi dalam melaksanakan pembangunan manusia itu sendiri yang merupakan titik pusat dari segala upaya pembangunan dan yang akan dibangun adalah kemampuan dan kekuatan sebagai pelaksana dan penggerak pembangunan. Dalam hal ini pemerintah yang memberikan pengawasan, bimbingan, bantuan, serta pembinaan kepada masyarakat.

\section{Pihak-pihak Pengguna Informasi Keuangan Desa}

Menurut Sujarweni (2015), pihak-pihak yang menggunakan informasikeuangan desa diantaranya adalah: masyarakat desa, perangkat desa, pemerintah daerah, dan pemerintah pusat.

\section{Anggaran Pendapatan dan Belanja Desa (APBDes)}

Anggaran pendapatan dan belanja desa (APBDes) adalah peraturan desa yang memuat sumber-sumber penerimaan dan alokasi pengeluaran desa dalam kurun waktu satu tahun.APBDes terdiri atas bagian pendapatan desa, belanja Desa dan pembiayaan. Rancangan APBDes dibahas dalam musyawarah perencanaan pembangunan desa. Penyusunan APBDes berdasar pada RKPDesa, yaitu rencana pembangunan tahunan yang ditetapkan dengan peraturan desa (Perdes). APBDes yang ditetapkan dengan peraturan Desa atau perdes, merupakan dokumen rencana kegiatan dan anggaran yang memiliki kekuatan hukum.

\section{Dana Desa}

Dana Desa adalah dana yang bersumber dari Anggaran Pendapatan dan Belanjan Negara yang diperuntukan bagi desa yang ditransfer melalui anggaran pendapatan dan belanja daerah kabupaten/kota gunakan untuk membiayai penyelenggaraan pemerintahan, pelaksanaan pembengunan pembinaan kemasyarakatan dan pemberdayaan masyarakat (Undang-Undang Nomor 6 Tahun 2014) Dana desa adalah 
salah satu isu krusial dalam undang-undang desa perhitungan anggaran berdasarkan jumlah desa dengan mempertimbangkan jumlah penduduk angka kemiskinan,luas wilayah,dan tingkat kesulitan geografis dalam meningkatkan kesejahteraan dan pemerataan pembangunan desa.

\section{Kekuasaan Pengelolaan Keuangan Desa}

Pemegang kekuasaan pengelolaan keuangan desa berdasarkan Permendagri nomor 113 tahun 2014 dipegang oleh Kepala desa. Namun dalam pelaksanaan pengelolaan keuangan desa, Kepala desa dibantu oleh PTPKD (Pelaksana Teknis Pengelola Keuangan Desa).

\section{Asas Pengelolaan Keuangan Desa}

Sujarweni (2015) mengemukakan bahwa keuangan desa dikelola berdasarkan asasasas transparan, akuntabel, dan partisipatif serta dilakukan dengan tertib dan disiplin anggaran. Rangkaian dan asas pengelolaan keuangan desa harus dilaksanakan dan dipenuhi oleh setiap desa agar penyelenggaraan pemerintahan, pelaksanaan pembangunan desa dapat berjalan sesuai dengan rencana, sehingga visi desa dan masyarakat yang sejahtera dapat diwujudkan. Keberhasilan akuntabilitas pengelolaan keuangan desa sangat dipengaruhi oleh isi kebijakan dan konteks implementasinya. Namun, di dalam pelaksanaannya tergantung bagaimana pemerintah melakukan pengawasan dan pembinaan terhadap pengelolaannya dalam mendukung keberhasilan program. Untuk mendukung keterbukaan penyampaian informasi secara jelas kepada masyarakat, setiap kegiatan fisik yang di danai dari dana desa supaya dipasang papan informasi kegiatan dilokasi dimana kegiatan tersebut dilaksanakan. Untuk mewujudkan pelaksanaan prinsip-prinsip transparansi dan akuntabilitas maka diperlukan adanya kepatuhan pemerintah desa khususnya yang mengelola dana desa sesuai dengan ketentuan yang berlaku.

\section{Alokasi Dana Desa}

Berdasarkan pada Peraturan Daerah Kabupaten Muna yang tertuang dalam Peraturan Bupati Nomor 08 Tahun 2016 tentang Pedoman Pengelolaan Alokasi Dana Desa. Alokasi Dana Desa (ADD) adalah dana perimbangan yang diterima Kabupaten/Kota Dalam Anggaran Pendapatan Belanja Daerah Kabupaten setelah dikurangi dana alokasi khusus, dialokasikan untuk desa paling sedikit 10\% (sepuluh persen). Melalui Alokasi dana Desa, diharapkan desa akan mampu menyelenggarakan otonominya agar dapat tumbuh dan berkembang mengikuti pertumbuhan dari desa itu sendiri. Dimana tujuan UU Desa adalah menciptakan masyarakat aktif yang mampu menjadi elemen utama dalam merencanakan, melaksanakan dan mengawasi setiap kegiatan pembangunan yang terjadi di desa.

\section{METODE PENELITIAN}

Objek dalam penelitian ini adalah berkaitan dengan hal-hal yang akan di bahas yaitu "Evaluasi pengelolaan dana desa di Desa Bone Kancintala Kecamatan Bone Kabupaten Muna" Jenis data yang digunakan dalam penelitian ini yaitu Data kualitatif yaitu data yang dinyatakan dalam bentuk pernyataan untuk mendeskripsikan mengenai Evaluasi Pengelolaan Dana Desa. Data kuantitatif yaitu data yang berupa angka-angka yang dapat diukur atau dinilai secara langsung. Sumber data dalam penelitian ini adalah data primer dan data sekunder. Data Primer adalah data yang pertama kali dicatat dan dikumpulkan oleh peneliti. Dalam hal ini adalah data dari hasil wawancara maupun observasi langsung oleh peneliti terkait hal yang diteliti. Dalam penelitian ini data primer didapatkan dari wawancara terhadap aparatur desa maupun masyarakat yang berhubungan langsung dengan pengelolaan Dana Desa. Data sekunder adalah data yang sudah tersedia yang kemudian digunakan peneliti sebagai data tambahan untuk memperjelas terkait hal yang diteliti. Data 
Jurnal Akuntansi dan Keuangan (JAK)

Volume 6, No. 1 Februari Tahun 2021

Page: $98-110$

http://ojs.uho.ac.id/index.php/jak-uho/issue/archive

e-ISSN: 2088-4656

sekunder dalam penelitian ini yaitu dokumen-dokumen yang dimiliki oleh pemerintah desa Bone Kacitaaa terkait pengelolaan Dana Desa.

Dalam penelitian ini tehnik yang digunakan untuk mengumpulkan data yaitu Wawancara (interview) adalah suatu kejadian atau suatu prosees interaksi antara pewawancara dan sumber informasi atau orang yang diwawancarai dapat dikatakan pula bahwa wawancara merupakan percakapan tatap muka antara pewawancara dengan sumber informasi, dimana pewawancara bertanya langsung tentang suatu objek yang diteliti dan telah dirancang sebelumnya (Yusuf, 2014: 372). Selanjutnya Dokumentasi adalah informasi yang berasal dari catatan penting baik dari lembaga atau organisasi maupun dari perorangan (Sugiyono, 2015). Dokumentasi penelitian ini merupakan pengambilan dokumen berupa laporan pertanggungjawaban dan data-data lain mengenai penggunaandana desa.

Setelah semua data dari hasil penelitian ini dikumpulkan maka data dikelompokkan menurut jenis dan sumbernya. Adapun teknik penganalisaan yang digunakan adalah analisis deskriptif, yaitu menggambarkan keadaan sesungguhnya sesuai dengan gejala-gejala dan permasalahan yang timbul dilapangan kemudian dibandingkan dengan Pemendagri Nomor 113 tahun 2014 tentang Pengelolaan Keuangan Desa.

\section{HASIL DAN PEMBAHASAN}

Tabel 4.1

APBDes Desa Bone Kancintala Kecamatan Bone Tahun Anggaran 2019

\begin{tabular}{|c|c|c|c|}
\hline $\begin{array}{l}\text { KODE } \\
\text { REK }\end{array}$ & URAIAN & $\begin{array}{l}\text { ANGGARAN } \\
\text { (Rp) }\end{array}$ & $\begin{array}{l}\text { SUMBER } \\
\text { DANA }\end{array}$ \\
\hline 1 & 3 & 4 & 5 \\
\hline 4 & PENDAPATAN & & \\
\hline 4.1 & Pendapatan Asli Desa & 1.000. 1.483 .095 & \\
\hline 4.2 & Pendapatan transfer & 1.483.095.138.00 & \\
\hline 4.3 & Dana Desa & 906.543.138,00 & \\
\hline & JUMLAH PENDAPATAN & $1.484 .095 .138,00$ & \multirow{5}{*}{$\mathrm{ADD}$} \\
\hline 5 & BELANJA & & \\
\hline 1 & $\begin{array}{l}\text { Bidang Penyelanggaraan } \\
\text { Pemerintah Desa }\end{array}$ & 473.252.000,00 & \\
\hline 1.1 & $\begin{array}{lr}\text { Penyelenggaraan } & \text { Belanja } \\
\text { Siltap,Tunjangan } & \text { dan } \\
\text { Operasional Pemerintahan Desa. }\end{array}$ & 403.002.040,00 & \\
\hline 1.1.01 & $\begin{array}{l}\text { Penyediaan penghasilan tetap dan } \\
\text { tunjangan kepala desa }\end{array}$ & 36.000 .000 & \\
\hline 1.1.01 & Belanja Pegawai & 36.000 .000 & \\
\hline 1.1.02 & $\begin{array}{l}\text { Penyediaan penghasilan tetap dan } \\
\text { tunjangan perangkat desa }\end{array}$ & $172.291 .440,00$ & ADD \\
\hline 1.1.02 & Belanja pegawai & $172.291 .440,00$ & \\
\hline 1.1.03 & $\begin{array}{l}\text { Penyedian Jaminan Sosial bagi } \\
\text { kepala desa dan perangkat desa }\end{array}$ & $16.719 .600,00$ & ADD \\
\hline 1.1.03 & Belanja Pegawai & $16.719 .600,00$ & \\
\hline
\end{tabular}


Jurnal Akuntansi dan Keuangan (JAK)

Volume 6, No. 1 Februari Tahun 2021

Page: 98 - 110

http://ojs.uho.ac.id/index.php/jak-uho/issue/archive

e-ISSN: 2088-4656

\begin{tabular}{|c|c|c|c|}
\hline $\begin{array}{l}\text { KODE } \\
\text { REK }\end{array}$ & URAIAN & $\begin{array}{l}\text { ANGGARAN } \\
\text { (Rp) }\end{array}$ & $\begin{array}{l}\text { SUMBER } \\
\text { DANA }\end{array}$ \\
\hline 1.1.04 & $\begin{array}{lr}\begin{array}{l}\text { Penyediaan } \\
\text { Pemerintahan Desa }\end{array} & \text { Operasional } \\
\text { PKPKD Dan PPKD dll) }\end{array}$ & $82.791 .000,00$ & $\mathrm{ADD}$ \\
\hline 1.1.04 & Belanja Barang Dan Jasa & $82.791 .000,00$ & \\
\hline 1.1 .05 & Penyedian Tunjangan BPD & $67.000 .000,00$ & ADD \\
\hline 1.1 .05 & Belanja Pegawai & $67.000 .000,00$ & ADD \\
\hline 1.1.06 & Belanja Operasional BPD & 9.000 .000 & ADD \\
\hline 1.1.06 & Belanja Barang dan Jasa & 9.000 .000 & \\
\hline 1.1.07 & $\begin{array}{ll}\text { Penyedian Insentif/Operasional } \\
\text { RT/RW }\end{array}$ & $19.200 .000,00$ & $\mathrm{ADD}$ \\
\hline 1.2 & $\begin{array}{|ll|}\text { Penyediaan Sarana } & \text { Prasana } \\
\text { Pemerintahan Desa } & \\
\end{array}$ & $34.000 .000,00$ & \\
\hline 1.2.01 & $\begin{array}{l}\text { Penyediaan Sarana (Aset Tetap) } \\
\text { Perkantoran }\end{array}$ & $18.400 .000,00$ & \\
\hline 1.2.02 & Belanja Barang Dan Jasa & $15.849 .960,00$ & \\
\hline 1.2 .03 & $\begin{array}{l}\text { Pemeliharaan Gedung/ Prasarana } \\
\text { Kantor Desa }\end{array}$ & $9.000 .000,00$ & \\
\hline 1.4 & $\begin{array}{lcc}\text { Penyelenggaraan } & \text { Tata } & \text { Praja } \\
\text { Pemerintahan, } & \text { Perencanaan, } \\
\text { Keunangan dan Pelaporan }\end{array}$ & $36.000 .00,00$ & \\
\hline 1.4.03 & $\begin{array}{l}\text { Penyusunan Dokumen Perncanaan } \\
\text { Desa (RPJMDesalRKPDesa) }\end{array}$ & 18.000.000,00 & $\mathrm{ADD}$ \\
\hline 1.4 .03 & Belanja Barang dan Jasa & $18.000 .000,00$ & \\
\hline 1.4 .04 & $\begin{array}{l}\text { Penyusunan Dokumen Keuangan } \\
\text { Desa (APBDes Perubahab LPG dan } \\
\text { lain-lain) }\end{array}$ & $5.000 .000,00$ & $\mathrm{ADD}$ \\
\hline 2 & $\begin{array}{l}\text { BIDANG PELAKSAANA } \\
\text { PEMBANGUNAN DESA }\end{array}$ & $317.644 .700,00$ & \\
\hline 2.1 & Sub Bidang Pendidikan & $159.924 .500,00$ & \\
\hline 2.1.01 & Belanja Barang Dan Jasa & 18.000 .000 & \\
\hline 2.1 .06 & $\begin{array}{l}\text { Pembangunan } \\
\text { Reahbilitas\Peningkatan\Pengadaan } \\
\text { Prasarana Alat Olahraga }\end{array}$ & $141.924 .500,00$ & $\mathrm{DD}$ \\
\hline 2.1 .06 & Belana Modal & $141.924 .500,00$ & \\
\hline 2.2 . & Sub Bidang Kesehatan & 6.000.000,00 & \\
\hline 2.2 .02 & $\begin{array}{l}\text { Penyelanggaraan Posyandu (Makan } \\
\text { Tambahan Bumi Lansia Insentif) }\end{array}$ & $6.000 .000,00$ & DDS \\
\hline 2.2 .02 & Belanja Barang dan Jasa & $6.000 .000,00$ & \\
\hline 2.3. & $\begin{array}{l}\text { Sub Bidang Pekerjaan Umum Dan } \\
\text { Penataan Ruang }\end{array}$ & $64.390 .000,00$ & \\
\hline 2.3.99 & $\begin{array}{l}\text { Lain-lain Kegiatan Sub Bidang } \\
\text { Pekerjaan Umum dan tata ruang }\end{array}$ & $64.390 .000,00$ & DDS \\
\hline 2.3.99 & Belanja Modal & $64.390 .000,00$ & \\
\hline 2.7 & \begin{tabular}{|l|l|l} 
Sub Bidang Energi dan \\
Sumberdaya Mineral
\end{tabular} & 87.330.000,00 & \\
\hline
\end{tabular}


Jurnal Akuntansi dan Keuangan (JAK)

Volume 6, No. 1 Februari Tahun 2021

Page: $98-110$

http://ojs.uho.ac.id/index.php/jak-uho/issue/archive

e-ISSN: 2088-4656

\begin{tabular}{|c|c|c|c|}
\hline $\begin{array}{l}\text { KODE } \\
\text { REK }\end{array}$ & URAIAN & $\begin{array}{l}\text { ANGGARAN } \\
\text { (Rp) }\end{array}$ & $\begin{array}{l}\text { SUMBER } \\
\text { DANA }\end{array}$ \\
\hline 2.7 .02 & $\begin{array}{l}\text { Pembangunan } \\
\text { Rehabilitas\Peningkatan\Sarana } \\
\text { dan Prasarana Energi Alternatif } \\
\text { Desa }\end{array}$ & $87.330 .000,00$ & \\
\hline 2.7 .02 & Belanja Brang dan Jasa & 7.043.000,00 & \\
\hline 2.7 .02 & Belanja Modal & $80.287 .200,00$ & \\
\hline 3 & $\begin{array}{|ll|}\text { Bidang } & \text { Pembinaan } \\
\text { Kemasyarakatan } & \\
\end{array}$ & $78.600 .000,00$ & \\
\hline 3.1 & $\begin{array}{l}\text { Sub Bidang Ketentraman, } \\
\text { Ketertiban Umum dan } \\
\text { Perlindungan Masyarakat }\end{array}$ & $3.600 .000,00$ & $\mathrm{ADD}$ \\
\hline 3.1 .02 & Keamanan Oleh Pemdes & $3.600 .000,00$ & \\
\hline 3.2 & Belanja Barang dan Jasa & $33.000 .000,00$ & \\
\hline 3.2.03 & $\begin{array}{l}\text { Sub Bidang Kebudayaan dan } \\
\text { Keagamaan }\end{array}$ & $15.000 .000,00$ & $\mathrm{ADD}$ \\
\hline 3.2 .02 & $\begin{array}{l}\text { Penyelenggraan Pestifal Kesenian } \\
\text { Adat Kebudayaan dan Keagamaan } \\
\text { (HUT Hari Raya Keagamaan Dll) }\end{array}$ & $15.000 .000,00$ & \\
\hline 3.2 .99 & Belanja Barang Dan Jasa & $18.000 .000,00$ & ADD \\
\hline 3.3 .06 & Belanja Barang dan Jasa & $2.400 .000,00$ & ADD \\
\hline 3.4 & $\begin{array}{l}\text { Sub Bidang Kepemudaan Dan } \\
\text { Olahraga }\end{array}$ & $2.400 .000,00$ & \\
\hline 3.3 .06 & $\begin{array}{l}\text { Pembinaan } \\
\text { kepemudaan }\end{array}$ Karangtaruna $\quad$ klub & $2.400 .000,00$ & \\
\hline 3.4 & Olahraga Tingkat Desa & $39.600 .000,00$ & \\
\hline 3.4 .01 & Belanja Brang dan Jasa & $10.800 .000,00$ & ADD \\
\hline 3.4.01 & $\begin{array}{l}\text { Sub Bidang Kelembagaan } \\
\text { Masyarakat }\end{array}$ & $10.800 .000,00$ & \\
\hline 3.4 .02 & Belanja Barang dan Jasa & $18.600 .000,00$ & \\
\hline 3.4 .03 & Pembinaan LKMD/LMP/LPMD & $10.200 .000,00$ & ADD \\
\hline 2.3 .99 & $\begin{array}{l}\text { Sub Bidang Kebudayaan Dan } \\
\text { Keagamaan }\end{array}$ & $64.390 .000,00$ & DDS \\
\hline 3.4 .03 & Belanja Barang dan Jasa & $10.200 .000,00$ & \\
\hline 2.3 .99 & Belanja Barang dan Jasa & $64.390 .000,00$ & \\
\hline 4 & Pembinaan PPK & $614.598 .438,00$ & \\
\hline 4.2 & Belanja Barang dan Jasa & $588.898 .438,00$ & \\
\hline 4.2 .99 & $\begin{array}{ll}\text { Bidang } & \text { Pemberdayaan } \\
\text { Masyarakat } & \end{array}$ & $588.898 .438,00$ & $\mathrm{ADD}$ \\
\hline 4.2 .99 & $\begin{array}{l}\text { Sub Bidang Pertanian dan } \\
\text { Peternakan }\end{array}$ & & \\
\hline 4.2 .99 & $\begin{array}{l}\text { Lain-lain Kegiatan Sub Bidang } \\
\text { Pertanian Dan Peternakan }\end{array}$ & $588.898 .438,00$ & \\
\hline 4.3 & Belanja Barang dan Jasa & $18.500 .000,00$ & \\
\hline 4.3 .99 & $\begin{array}{l}\text { Sub Bidang Peningkatan Kapasitas } \\
\text { Aparatur Desa }\end{array}$ & $18.500 .00,00$ & ADD \\
\hline
\end{tabular}


Jurnal Akuntansi dan Keuangan (JAK)

Volume 6, No. 1 Februari Tahun 2021

Page: $98-110$

http://ojs.uho.ac.id/index.php/jak-uho/issue/archive

e-ISSN: 2088-4656

\begin{tabular}{|c|c|c|c|}
\hline $\begin{array}{l}\text { KODE } \\
\text { REK }\end{array}$ & URAIAN & $\begin{array}{l}\text { ANGGARAN } \\
\text { (Rp) }\end{array}$ & $\begin{array}{l}\text { SUMBER } \\
\text { DANA }\end{array}$ \\
\hline 4.3 .99 & \begin{tabular}{|lcc} 
Lain-Lain $\quad$ Kegiatan & Sub \\
Peningkatan Aparatur Desa & \\
\end{tabular} & $18.500 .000,00$ & ADD \\
\hline 4.4 & Belanja Barang dan Jasa & $7.200 .000,00$ & \\
\hline 4.4 .01 & $\begin{array}{l}\text { Sub Bidang Pemberdayaan } \\
\text { Perempuan, Perlindungan Anak dan } \\
\text { Keluarga }\end{array}$ & 7.200.000,00 & \\
\hline \multirow[t]{4}{*}{4.4 .01} & \begin{tabular}{|l|l} 
Pelatihan dan Penyuluhan \\
Pemberdayaan Perempuan
\end{tabular} & $7.200 .000,00$ & \\
\hline & JUMLAH BELANJA & 1.484.095.138,00 & \\
\hline & SIRPLUS \(DEFISIT) & $\mathbf{0 , 0 0}$ & \\
\hline & $\begin{array}{l}\text { SISA LEBIH (KURANG) } \\
\text { PERHITUNGAN ANGGARAN }\end{array}$ & $\mathbf{0 , 0 0}$ & \\
\hline
\end{tabular}

Dari tabel 4.1 dapat diketahui bahawa Pendapatan Desa Bone Kancintala sebesar Rp 1.484.095.138,000 Yang terbagi atas Pendapatan Asli Desa sebesar Rp 1.000.000.00, Pendapatan Transfer sebesar Rp 1.483.095.138,00 . Jumlah Belanja sebesar Rp 1.484.095.138,00 yang terbagi atas bidang penyelenggaraan pemerintah desa sebesar $\mathrm{Rp}$ 473.252.000,00 bidang pelaksanaan pembangunan desa sebesar Rp 317.644.700,00 bidang pembinaan kemasyarakatan sebesar Rp 614.598.000,00 dan pemberdayaan masyarakat sebesar Rp 614.598.438,00. serta jumlah Pembiayaan sebesar Rp 93.200.000.00 Sehingga sisa lebih/ (kurang) perhitungan sebesar Rp 0,00.

Dari hasil wawancara yang telah dilakukan, Pemerintah Desa Bone Kancintala Kecamatan Bone dalam perencanaan berdasarkan RKPDes, yang dilakukan dengan prinsip partisipasi dan transparansi.Perencanaan dengan model partisipatif dilakukan melalui musyawarah dusun yang membahas usulan-usulan perencanaan, selanjutnya dilakukan musrembang desa untuk menentukan program pembangunan desa yang akan ditetapkan dalam APBDes.

Hal tersebut seperti yang diungkapkan oleh Sekretris Desa berikut:

“ Proses pembuatan APBDes, pertama kepala desa mendengarkan masukan dari masyarakat desa Dusun I dan Dusun II. Setelah itu di RAPBDesa (Rancangan anggaran pendapatan dan belanja desa), kemudian RAPBDes dimusyawarakan dan disampaikan dilembaga BPD.Jadi sebelum ditetapkan APBDes pemerintah menggali masukan dari masyarakat, selanjutnya pemerintah desa membuat RAPBDes dan dimusyawarakan dengan BPD dan Pelaksana Teknis Pengelolaan Keuangan Desa.Setelah dimusyawarakan dan mendapat kesepakatan maka ditetapkan yang namanya APBDes" (Hasil wawancara dengan Sekretaris Desa).

Musyawarah desa membuka kesempatan untuk masyarakat dalam menyampaikan aspirasinya sekaligus sebagai media belajar bagi masyarakat terhadap prinsip akuntabilitas pengelolaan DD. Unsur yang diundang dalam musyawarah desa ini meliputi Kepala Desa, Badan Permusyawaratan Desa (BPD), Kepala Dusun, Perangkat Desa, Unsur LPMD dan Unsur Kelembagaan Desa.

Hal tersebut dibuktikan dari hasil wawancara dengan informan yang mengatakan: "Iya dapat memberikan manfaat, karena dengan adanya musyawarah maka aspirasi/ pendapat kami masyarakat dapat kita sampaikan dalam musyawah" (Hasil wawancara dengan salah satu masyarakat). 
Jurnal Akuntansi dan Keuangan (JAK)

Volume 6, No. 1 Februari Tahun 2021

Page: $98-110$

http://ojs.uho.ac.id/index.php/jak-uho/issue/archive

e-ISSN: 2088-4656

Tabel 4.8 Pembangunan yang bersumber dari Dana Desa

\begin{tabular}{|c|c|c|c|c|c|}
\hline Uraian & Output & $\begin{array}{l}\text { Volu } \\
\text { me }\end{array}$ & $\begin{array}{c}\text { Cara } \\
\text { pengadaa } \\
\mathbf{n}\end{array}$ & Anggaran & $\begin{array}{c}\text { Capa } \\
\text { ian } \\
\text { outp } \\
\text { ut } \\
(\%)\end{array}$ \\
\hline$\overline{1}$ & 2 & 3 & 4 & 5 & 6 \\
\hline \multicolumn{6}{|l|}{ PENDAPATAN } \\
\hline \multicolumn{6}{|l|}{$\begin{array}{l}\text { Pendapatan } \\
\text { Transfer }\end{array}$} \\
\hline$-\quad$ Tahap I & & & & 376.486 .520 & $50 \%$ \\
\hline Tahap II & & & & 362.617 .300 & $50 \%$ \\
\hline $\begin{array}{l}\text { JUMLAH } \\
\text { PENDAPATAN }\end{array}$ & & & & 739.617.300 & $\begin{array}{l}100 \\
\%\end{array}$ \\
\hline 1 & 2 & 3 & 4 & 5 & 6 \\
\hline \multicolumn{6}{|l|}{ BELANJA } \\
\hline $\begin{array}{l}\text { - Bidang } \\
\text { pelaksanaan } \\
\text { pembangunan } \\
\text { desa } \\
\end{array}$ & & & & 764.582 .700 & - \\
\hline $\begin{array}{l}\text { Kegiatan } \\
\text { pembangunan } \\
\text { sarana air bersih }\end{array}$ & & & & 56.434 .000 & \\
\hline
\end{tabular}

\begin{tabular}{|c|c|c|c|c|c|}
\hline $\begin{array}{l}\text { - Kegiatan } \\
\text { pembangunan } \\
\text { WC }\end{array}$ & $\begin{array}{l}\text { - Pembanguna } \\
\text { n PAH }\end{array}$ & 7 & $\begin{array}{l}\text { Swakel } \\
\text { ola }\end{array}$ & $\begin{array}{l}435.28 \\
1.000\end{array}$ & $100 \%$ \\
\hline & $\begin{array}{l}\text { - Pembanguna } \\
\text { n WC }\end{array}$ & & & & \\
\hline $\begin{array}{l}\text { - } \quad \text { Kegiatan } \\
\text { pembangunansar } \\
\text { ana prasarana } \\
\text { olahraga }\end{array}$ & $\begin{array}{l}\text { - Pengadaan } \\
\text { lap. Olahraga }\end{array}$ & 30 & $\begin{array}{l}\text { Swakel } \\
\text { ola }\end{array}$ & $\begin{array}{l}240.86 \\
1.000\end{array}$ & $100 \%$ \\
\hline \multirow[t]{3}{*}{$\begin{array}{l}\text {-Bidang } \\
\text { pemberdayaan } \\
\text { masyarakat }\end{array}$} & $\begin{array}{l}\text { - Intensif guru } \\
\text { PAUD }\end{array}$ & & & $\begin{array}{l}6.000 .0 \\
00,00\end{array}$ & \\
\hline & & $1 \mathrm{Ls}$ & $\begin{array}{l}\text { Swakel } \\
\text { ola }\end{array}$ & $\begin{array}{l}240.86 \\
1.000\end{array}$ & $100 \%$ \\
\hline & & $1 \mathrm{Ls}$ & $\begin{array}{l}\text { Swakel } \\
\text { ola }\end{array}$ & $\begin{array}{l}6.000 .0 \\
00\end{array}$ & $100 \%$ \\
\hline $\begin{array}{l}\text { JUMLAH } \\
\text { BELANJA }\end{array}$ & & & & $\begin{array}{l}1.211 .4 \\
20.00\end{array}$ & \\
\hline \multicolumn{5}{|l|}{ PEMBIAYAAN } & \\
\hline $\begin{array}{l}\text { - SILPA Tahun } \\
\text { sebelumnya }\end{array}$ & $\begin{array}{l}\text { SILPA thn } \\
2016\end{array}$ & & $\begin{array}{l}\text { Swakel } \\
\text { ola }\end{array}$ & $\begin{array}{l}4.373 .0 \\
00\end{array}$ & \\
\hline
\end{tabular}


Jurnal Akuntansi dan Keuangan (JAK)

Volume 6, No. 1 Februari Tahun 2021

Page: $98-110$

http://ojs.uho.ac.id/index.php/jak-uho/issue/archive

e-ISSN: 2088-4656

\begin{tabular}{|c|c|c|c|c|}
\hline $\begin{array}{l}\text { - Penyertaan } \\
\text { modal }\end{array}$ & BUMDes & \begin{tabular}{|l} 
Swakel \\
ola
\end{tabular} & $\begin{array}{l}106.87 \\
3.000\end{array}$ & \\
\hline $\begin{array}{l}\text { JUMLAH } \\
\text { PEMBIAYAAN }\end{array}$ & & & & \\
\hline $\begin{array}{l}\text { JUMLAH } \\
\text { (PENDAPATAN } \\
\text {-BELANJA- } \\
\text { PEMBIAYAAN) }\end{array}$ & & \multicolumn{2}{|c|}{93.200 .000 .00} & $\begin{array}{l}100 \\
\%\end{array}$ \\
\hline
\end{tabular}

sumber: Laporan Pertanggungjawaban Dana Desa tahun 2019(diolah)

Tabel 4.8menunjukkan bahwa Pembangunan penampungan sarana air bersih (PAH) sebanyak 7 unit dengan realisasi 100\%, pembangunan WC/Komunal sebanyak 30 unit dengan realisasi $100 \%$, dan Pengadaan laparangan olahraga terealisasi $100 \%$. Semua kegiatan yang didanai Dana desa tahun 2019 dilaksanakan secara swakelola. Sehingga hasil yang dicapai dari pengelolaan dana desa ini dapat dipertanggungjawabkan dengan baik.

Penyelenggaraan pemerintahan desa harus transparansi dan akuntabilitas dimana semua hal yang terkait dengan penyenggaraan pemerintahan desa harus dapat diakses oleh camat, inspektorat kabupaten/kota, BPK, dan warga desa,disamping itu, pemerintah desa harus mempertanggungjawabkan penyelenggaraan pemerintahaanya kepada pemerintah atasan, BPD, dan Masyarakat.

\section{Pembahasan}

\section{Tahap Perencanaan}

Penting bagi pemerintah desa untuk merencanakan pengelolaan APBDes agar pembangunan dapat terlaksana dengan baik dan terarah.Hal ini dapat dilihat dalam perencanaan program dan kegiatan di Desa Bone Kancintala dilakukan dengan prinsip transparansi dan partisipasitif dimana perencanaannya disusun melalui forum musyawarah dari dusun ke musyawarah desa (MusDes). Musyawarah desa merupakan forum pembahasan usulan rencana kegiatan pembangunan tingkat desa yang mengharuskan keterlibatan masyarakat dalam pengambilan keputusan dan menentukan pembangunan yang akan dilaksanakan di Desa Bone Kancintala Kecamatan Bone, sehingga benar-benar dapat merespon kebutuhan/aspirasi yang berkembang. Kesepakatan juga harus transparan, dapat diketahui oleh masyarakat desa yang nantinya dapat dipertanggungjawabkan.

Perencanaan pembangunan desa berdasarkan permendagri nomor 114 tahun 2014 pada bab I ketentuan umum menjelaskan bahwa perencanaan pembangunan desa sesuai dengan kewenangannya dengan mengacu pada perencanaan pembangunan kabupaten dan kota. Rencana pembangunan desa disusun untuk menjamin keterkaitan dan konsistensi antara perencanaan, penganggaran, pelaksanaan, dan pengawasan (sujarweni,2015;18). Prinsip Transparansi atau keterbukaan berarti keputusan yang diambil dan pelaksanaannya dilakukan dengan cara atau mekanisme yang mengikuti aturan atau regulasi yang ditetapkan oleh lembaga. Sedangkan Prinsip partisipasi Tjokroamidjojo dalam Subroto (2009: 36) adalah keterlibatan setiap warga Negara dalam pengambilan keptususan baik secara langsung maupun melalui institusi yang mewakili kepentingannya.

Akuntabilitas dalam tahap perencanaan pengelolaan dana desa di Desa Bone Kancintala Kecamatan Bone berdasarkan hasil analisis data wawancara yang telah dipaparkan bahwa program yang akan dibangun dengan dana desa berdasarkan dari usulan prioritas masyarakat untuk kesejahteraan masyarakat. Selain itu pemerintah desa harus mempertanggungjawabkan RPJMDesa yang merupakan dokumen yang memuat arah kebijakan pembangunan desa dan acuan dasar program kerja pemerintah. Pemerintah Desa 
Bone Kancintala juga wajib mempertanggungjawabkan peaksanaan RKPDesa yang telah disusun, karena RKPDesa merupakan rencana kerja tahunan yang akan dilaksanakan pemerintah desa dan menjadi acuan dalam pembuatan perubahan APBDesa.

\section{Tahap Pertanggungjawaban}

Setelah membuat laporan, pemerintah desa wajib menyampaikan pertanggungjawabanya setiap item kegiatan baik kepada Bupati/walikota maupun kepada masyarakat.Berdasarkan hasil analisis data yang telah dipaparkan maka akuntabilitas pemerintah Desa Bone Kancintala dalam pertanggungjawaban yaitu sebelum pelaksanaan kegiatan terlebih dahulu dipapampangkan baliho APBDes yang memuat jumlah anggaran. Selain itu tiap tahapan membuat laporan pertanggung jawaban dana desa untuk tahap I, dan II. Laporan ini selain untuk Bupati juga untuk BPD, dan masyarakat.Setelah rampung pengerjaan pemerintah desa membuat papan informasi yang dipasang dibalaydesa mengenai volume pembangunan yang dikerjakan, sehingga apabila ada masyarakat ingin mengetahui volume pembangunan dapat dilihat dibalaydesa.Berdasarkan teori tersebut dan juga pembahasan sebelumnya, maka hal menunjukan bahwa Desa Bone Kancintala telah mempertanggungjawabkan secara langsung pelaksanaan Dana Desa yang dimuat dalam APBDes yang dilakukan secara partisipatif, transparan, dan akuntabel.

\section{Kesimpulan}

\section{KESIMPULAN DAN SARAN}

Kesimpulan dari hasil penelitian dan pembahasan yang dikemukakan sebelumnya, adalah sebagai berikut :

Tahap Perencanaan Dana Desa di Desa Bone Kancintala Kecamatan Bone Kabupaten Muna telah menerapkan prinsip partisipasi dan transparasi dan Tahap Pertanggungjawaban Pengelolaan Dana Desa Di Desa Bone Kancintala sudah Akuntabel dan secara teknis sudah baik. Kegiatan pembangunan $100 \%$ telah terealisasi.

\section{Keterbatasan}

Beberapa keterbatasan dalam penelitian ini yang dapat mempengaruhi hasil penelitian adalah sebagai berikut :

1. Objek dan sampel penelitian yang diambil hanya terbatas pada satu perwakilan instansi saja bukan beberapa instansi.

2. Penelitian hanya menggunakan metode wawancara sebagai metode pengumpulan data dan tidak melakukan secara mendalam dengan semua responden dalam penelitian.

\section{Implikasi}

Berdasarkan dari hasil penelitian dan pembahasan pengelolaan Dana Desa di Desa Bone Kancintala Kecamatan Bone Kabupaten Muna Tahun 2019 yang telah dipaparkan pada bab sebelumnya, bahwasanya ada beberapa kesimpulan yang dapat diambil sudah sesuai dengan aturan-aturan yang termuat dalam permendagri Nomor 113 Tahun 2014 Tentang Evaluasi Pengelolaan Dana Desa, diantaranya Tahap Perencanaan Dana Desa di Desa Bone Kancintala Kecamatan Bone Kabupaten Muna telah menerapkan prinsip partisipasi dan transparasi dan Tahap Pertanggungjawaban Pengelolaan Dana Desa Di Desa Bone Kancintala sudah Akuntabel dan secara teknis sudah baik. Kegiatan pembangunan $100 \%$ telah terealisasi.

\section{Rekomendasi}

Saran dari kesimpulan yang dikemukakan sebelumnya, adalah sebagai berikut:

1. Pemerintah desa perlu mendirikan papan informasi untuk rincian kegiatan seperti jenis pekerjaan, jangka waktu pekerjaan, dan volume pekerjaan agar masyarakat dapat mengetahui dengan muda. 
Jurnal Akuntansi dan Keuangan (JAK)

Volume 6, No. 1 Februari Tahun 2021

Page: $98-110$

http://ojs.uho.ac.id/index.php/iak-uho/issue/archive

e-ISSN: 2088-4656

2. Dalam kegiatan yang didanai dana desa Pemerintah desa perlu meningkatkan pembinaan dan pemberdayaan masyarakat.

3. Peneliti selanjutnya disarankan untuk menambahkan informan yaitu masyarakat desa dalam pengumpulan data melalui wawancara untuk dapat menilai pertanggungjawaban pemerintah desa dalam pengelolaan Dana Desa.

\section{DAFTAR PUSTAKA}

Badan pengawasan Keuangan dan pembangunan 2015. Deputi Bidang pengawasan Penyelenggaraan Keuangan Daerah: Petunjuk dan Pelaksaan Bimbingan dan Konsultasi Pengelolaan Keuangan Desa.

Dini, Gemala Sari. (2010). Hubungan Alokasi dana Desa Dengan Pembangunan Desa di Kecamatan Staba Kabupaten Langkat. Tesis. Pascasarjana Universitas Sumatera Utara Medan.

Hargono, Didie Setiabudi. 2010. Efektivitas Penyaluran Dana Desa Pada Empat Desa di Kabupaten Karangsem Provinsi Bali. Tesis. Universitas Indonesia Jakarta.

Hasbudin. Safaruddin dan Tuti Dharmawati. 2015. AkuntansiKeuangan Desa. Kendari: Hispisi Sultra.

Listiyani, Rini. 2016. Efektivitas Implementasi kebijakan Penggunaan dana Desa Tahun Anggaran 2015 di Desa Gunungpriring Kecamatan Luntilang Kabupaten Magelang. Jurnal, FIS UNY.

Mardiasmu. 2009. Akuntansi Sektor Publik. Yogyakarta. Penerbit CV. Andi off set.

Nurcholis. (2011). Akuntansi Keuangan Desa (Akuntansi Keuangan Desa). Jakarta: Indeks.

Peraturan Menteri Dalam Negeri Nomor 113 Tahun 2014 Tentang Pengelolaan Dana Desa.

Peraturan Menteri Desa, pembangunan Daerah Tertinggal, dan Transmigrasi Nomor 3 Tahun 2015 Tentang Pendamping Desa.

Peraturan Pemerintah Nomor 22 Tahun 2015 Tentang Perubahan Atas Peraturan Pemerintahan Nomor 60 Tahun 2014 Tentang Dana Desa Yang Bersumber Dari Anggaran Pendapatan dan Belanja Negara.

Peraturan Pemerintah Nomor 47 Tahun 2015 Tentang Perubahan Atas Peraturan Pemerintahan Nomor 43 Tahun 2014 Tentang Peraturan Pelaksanaan Undang-Undang Nomor 6 Tahun 2014 Tentang Desa.

Peraturan Pemerintah Nomor 71 Tahun 2010 Tentang Standar Akuntansi Pemerintahan.

Republik Indonesia Undang-Undang Nomor 32 Tahun 2004 Tentang Pemerintah Daerah Jakarta Publik.

Sujarweni V.W. 2015. Akuntansi Sektor Publik. Yogyakarta.: Penerbit Pustaka Baru Press.

Undang-Undang Nomor 6 Tahun 2014 Tentang Desa.

Yuliansyah. (2016). Siklus Pengelolaan Keuangan Desa. Dalam Proses Pengelolaan Keuangan Desa.

Yusuf, A. M 2014. Metodologi Penelitian Kuantitatif, Kualitatif dan Penelitian Gabungan, Jakarta: PRENAMEDIA GROUP 